\title{
Accumulation, Translocation, and Toxicity of Arsenic in Barley Grown in Contaminated Soil
}

\author{
Marina Burachevskaya \\ Southern Federal University \\ Tatiana Minkina \\ Southern Federal University \\ Alexey Fedorenko \\ Southern Federal University \\ Grigorii Fedorenko \\ Southern Federal University \\ Natalia Chernikova \\ Southern Federal University

\section{Saglara Mandzhieva} \\ Southern Federal University

\section{Tatiana Bauer} \\ Southern Federal University
}

Vishnu D. Rajput ( $\nabla$ rajput.vishnu@gmail.com )

Southern Federal University https://orcid.org/0000-0002-6802-4805

\section{Research Article}

Keywords: Bioaccumulation, Crops • Haplic Chernozem, Soil contamination, Metalloid

Posted Date: March 2nd, 2021

DOl: https://doi.org/10.21203/rs.3.rs-264946/v1

License: (c) (i) This work is licensed under a Creative Commons Attribution 4.0 International License. Read Full License

Version of Record: A version of this preprint was published at Plant and Soil on July 23rd, 2021. See the published version at https://doi.org/10.1007/s11104-021-05067-9. 


\section{Abstract}

Aims Arsenic is a nonessential element for plants, however, high levels of As can inhibit plant growth. Toxicity of As is largely influenced by its speciation in soil. The objectives of the present study were to determine fractional composition of As in soil, its accumulation in plants, and toxic effects on the morphological, anatomical, and ultrastructural levels.

Methods In a model experiment, barley (Hordeum sativum) was planted in Haplic Chernozem spiked with three different concentrations of As (20,50 and $100 \mathrm{mg} / \mathrm{kg})$. The fraction composition of As in the experimental soil was analysed using a method of sequential fractionation. The effect of As on plants was analysed microscopically at tissue, cellular, and intracellular levels.

Results Analysis of the fraction composition of As revealed a higher amount of mobile forms of As that contaminated the generative organs of plants. Oxides of $\mathrm{Fe}, \mathrm{Al}$, and $\mathrm{Mn}$ became the main soil components to retain As when contamination of As increased. Arsenic toxicity inhibited plant growth by affecting morphological parameters (shape, size, and colour). It was shown impairment in the root cells and a reduction in the size of the chlorophyllic parenchyma in the leaves. Ultrastructural analysis found changes in the main cellular organelles (chloroplasts, mitochondria, and peroxisomes).

Conclusions The bioconcentration factor (BCF), bioaccumulation factor (BF-soluble), and translocation factor (TF) allowed evaluation of plant protection mechanisms and determination of hazardous concentrations of As in soil. Despite high buffering capacity of soil, high As concentration affected morphological and ultrastructural parameters of the $H$. sativum.

\section{Introduction}

Pollution of the environment by As is a global problem due to its toxicity, risk to human health, and contribution to the development of skin and lung cancers caused through bioaccumulation of this metal in plant tissues and organs consumed by humans and animals (Bundschuh et al. 2012; Tong et al. 2014; Oberoi et al. 2019; Palma-Lara et al. 2020).

The content of As in Chernozem soils in the Russian steppes ranges from $1.1 \mathrm{mg} / \mathrm{kg}$ to $150 \mathrm{mg} / \mathrm{kg}$ (Motuzova et al. 2006) in association with its presence in soil-forming rocks. In the North Caucasus high concentration of As attributed to the presence of rocks rich in polymetallic ores in the region. Typical concentrations of As in the world in uncontaminated soils range from $0.1 \mathrm{mg} / \mathrm{kg}$ to $40 \mathrm{mg} / \mathrm{kg}$ (Bowen, 1979). The total amount of As in Earth's upper crust is estimated to be $4.01 \cdot 10^{16} \mathrm{~kg}$ with an average content of $6 \mathrm{mg} / \mathrm{kg}$ (Taylor and McLennan 1985; Nriagu and Azcue 1994; Matschullat 2000). In addition to natural sources, As may enter soil as a byproduct of anthropogenic activities such as manufacturing and widespread application of insecticides, herbicides, defoliants, feed additives for livestock, wood preservatives, and the burning, mining, and smelting of coal and other nonferrous metals (Smith et al. 1998).

The transfer of As from contaminated soils to agricultural crops poses potential health risks to humans through exposure to contaminated soils and consumption of food crops grown on them (Otones et al. 2011; Antoniadis et al. 2017). Moreover, plant growth, metabolism, respiration, photosynthesis, and opening of stomata can be adversely affected by elevated levels of As. The accumulation of As and other pollutants in plant tissue depends on the plant species, and their capacity to adsorb pollutants which can be assessed by measuring rates of uptake and other soil-to- 
plant transfer factors (Adamo et al. 2014; Antoniadis et al. 2017). In food crops, As uptake is highly variable and appears to be higher in green vegetables and grain crops compared to other crops grown in contaminated soils (Kabata-Pendias and Mukherjee 2007; Rahman et al. 2007). The bioavailability of As for plants is determined by soil properties, notably mineral composition, organic matter content, $\mathrm{pH}$, and redox potential (Tu and Ma 2003; Warren et al. 2003; Antoniadis et al. 2017; Zhao et al. 2020). The biogeochemistry of As is not well understood due to the complexity of the fractioning methods used to analyse the composition and diversity of various As compounds (Motuzova et al. 2006; Adamo et al. 2014; Ma et al. 2017; Mathee et al. 2018).

To date, there is no reliable data on soil components that fix As and contribute to its bioavailability in soils in natural landscapes. The biogeochemistry and bioavailability of As in Chernozem soils is still insufficiently studied; thus, analysis of As uptake in Chernozem soils is an important research objective because of the effect of As on the morphological, biometric, and ultrastructural parameters of plants grown in contaminated soil (Fitz and Wenzel 2002; Otones et al. 2011; Pandey and Bhatt 2016). Speciation of As in Haplic Chernozem was investigated for the first time using an sequential extraction procedure (Motuzova et al. 2006). This method has advantages in extracting As compounds and can isolate up to six fractions. A combination of sequential extraction and microscopic analysis allowed us to estimate the bioavailability, uptake mechanism, and potential risk posed by As for barley (Hordeum sativum L.), one of the most important food crops in the world (Arendt and Zannini 2013) and widely used as a bioindicator to assess the impact and accumulation of pollutants (Minkina et al. 2018; Rajput et al. 2020).

The main objective of this study was to investigate As uptake by the $H$. sativum from Haplic Chernozem from North Caucasus and to identify the impact of As on the morphological, anatomical, and ultrastructural characteristics of the plants.

\section{Materials And Methods}

Soil characteristics

The upper horizon of uncontaminated soil (Haplic Chernozem according to the WRB 2015) collected from the Persianovskaya Steppe Nature Reserve (Rostov region) was sampled. The samples were collected by mixing five initial samples from surface horizons (0 to $20 \mathrm{~cm}$ ), stored in polyethylene bags and taken directly to the laboratory for analysis. Soil sampling was performed in accordance with ISO 18400-104 (2018) procedures and standards. The soil samples were mixed, air dried, sifted through a $2 \mathrm{~mm}$ sieve, and homogenised. The main physical-chemical soil properties analysed are presented in Table 1 . The hydrogen ion concentration $(\mathrm{pH})$ was analysed potentiometrically in a soil paste saturated with water. The cation exchange capacity (CEC) was estimated using the ammonium acetate method (Tan 1996), and the exchangeable cations were analysed using $1 \mathrm{M} \mathrm{NH}_{4} \mathrm{OAc}$ (Vorob'eva 2006). Organic matter was evaluated by dichromate oxidation using the Tyurin method (Jackson 1960), and particle-size distribution was determined using the pipette method (pyrophosphate procedure for soil preparation (Shein 2009).

Table 1

Physical and chemical properties of Haplic Chernozem $(0-20 \mathrm{~cm})$

\begin{tabular}{|c|c|c|c|c|c|c|}
\hline $\begin{array}{l}\text { Silt particles }(<0.02 \\
\mathrm{mm}), \%\end{array}$ & $\begin{array}{l}\text { Clay particles (< } \\
0.002 \mathrm{~mm}), \%\end{array}$ & $\begin{array}{l}C_{\text {org., }} \\
\%\end{array}$ & $\mathrm{pH}$ & $\begin{array}{l}\mathrm{CaCO}_{3}, \\
\%\end{array}$ & $\begin{array}{l}\mathrm{Ca}^{2+}+\mathrm{Mg}^{2+} \\
\mathrm{mmol}(+) / 100 \mathrm{~g}\end{array}$ & $\begin{array}{l}\text { CEC, } \\
\text { mmol(+)/100 } \\
\mathrm{g}\end{array}$ \\
\hline $48.1 \pm 1.4^{\star}$ & $28.6 \pm 1.2$ & $\begin{array}{l}3.7 \pm \\
0.3\end{array}$ & $\begin{array}{l}7.3 \pm \\
0.1\end{array}$ & $\begin{array}{l}0.3 \pm \\
0.1\end{array}$ & $35.0 \pm 3.0$ & $37.1 \pm 2.9$ \\
\hline
\end{tabular}


The composition of the exchangeable bases, a high amount of organic matter, the presence of highly dispersed micellar forms of carbonates, and loess-like parent rocks produced favourable physical properties in Haplic Chernozem (i.e., permeability to water and air, high porosity, and moisture capacity).

Plant growth conditions and sampling methods

The artificial application of different doses of As allowed us to trace the changes of the soil system under varying anthropogenic loads to predict the strength of metalloid fixation by the soil at different levels of contamination. A 3$\mathrm{cm}$ layer of washed glass was placed on the bottom of 2-L plastic vessels to provide liter for drainage, and $2 \mathrm{~kg}$ soil was added. Next, different doses of arsenic oxide $\left(\mathrm{As}_{2} \mathrm{O}_{3}\right)$ were added as dry powder to each of the treatment vessels and thoroughly mixed into the soil. Approximate permissible concentrations (APC) for As in neutral and slightly alkaline soils is $10 \mathrm{mg} / \mathrm{kg}$ (GN 2.1.7.2511/09). Pollution doses used in this study were similar to levels of As in anthropogenically-polluted soils. The doses of As corresponded to low (2 APC), high (5 APC), and very high (10 APC) degrees of contamination in soil. The study included three treatment doses $(20,50$, and $100 \mathrm{mg} / \mathrm{kg}$ of As) and a control (uncontaminated soil sample). Each treatment was prepared in triplicate.

Soil incubation took place at a temperature of $20-22^{\circ} \mathrm{C}$ under natural light conditions. Optimal humidity of $60 \%$ of the total moisture capacity of soil was maintained in the vessels throughout the experiment. After two months of soil incubation, the $H$. sativum was sown. Previous research demonstrated that two months is sufficient time for transformation process of pollutants in the Haplic Chernozem (Ladonin and Karpukhin 2011; Minkina et al. 2018). Twelve plants were grown in each vessel (4 treatment variants with 3 replications each, for a total of 144 plants). No additional fertilisers or pesticides were applied during the experiment. Each treatment was prepared in triplicate and the position of the vessels was changed randomly every week. After the harvesting plants, the soil samples were taken.

\section{Determination of arsenic in soil samples}

The composition of As complexes in the experimental soil was analysed using a method of sequential fractionation of metalloids developed by Motuzova et al. (2006). In present study, the most ecologically-important compounds were extracted. Metalloid compounds were divided into mobile forms (specifically and nonspecifically adsorbed arsenate ions), strongly bound forms (low-solubility arsenates and As in primary and secondary minerals), and As compounds associated with oxides of $\mathrm{Fe}, \mathrm{Al}$, and $\mathrm{Mn}$ and organic substances (Table 2). The main advantage of this method is the use of $0.1 \mathrm{~N} \mathrm{NaOH}$ instead of $30 \% \mathrm{H}_{2} \mathrm{O}_{2}$ followed by dissolution of the residue in $1 \mathrm{~N} \mathrm{CH}_{3} \mathrm{COONH}_{4}$ and is often used to extract trace elements from soil organic matter (Tessier et al. 1973; Ure et al. 1993; Matera et al. 2003). 
Table 2

A scheme for sequential fractionation of As in the soil

\begin{tabular}{|c|c|c|}
\hline Extractant & Fraction & Conditions \\
\hline $\begin{array}{l}1 \%\left(\mathrm{NH}_{4}\right)_{2} \mathrm{SO}_{4}+0.25 \% \\
\left(\mathrm{NH}_{4}\right)_{2} \mathrm{MoO}_{4}, \mathrm{pH} 5.5-6.0\end{array}$ & $\begin{array}{l}\text { Nonspecifically adsorbed } \\
\text { (exchangeable ions, easily } \\
\text { soluble salts) }\end{array}$ & $\begin{array}{l}\text { Soil : solution }=1: 50,4 \text { h shaking, } 10 \mathrm{~min} \\
\text { centrifuging }(4000 \mathrm{rpm})\end{array}$ \\
\hline $1 \mathrm{M} \mathrm{NH}_{4} \mathrm{H}_{2} \mathrm{PO}_{4}, \mathrm{pH} 5.5-6.0$ & Specifically adsorbed ions & $\begin{array}{l}\text { Soil : solution }=1: 50,4 \mathrm{~h} \text { shaking, } 10 \mathrm{~min} \\
\text { centrifuging }(4000 \mathrm{rpm})\end{array}$ \\
\hline $\begin{array}{l}0.5 \mathrm{M} \mathrm{Na}_{3} \mathrm{C}_{6} \mathrm{H}_{5} \mathrm{O}_{7}+1 \mathrm{M} \\
\mathrm{NaHCO}_{3}+0.13 \mathrm{M} \\
\mathrm{Na}_{2} \mathrm{~S}_{2} \mathrm{O}_{4} \star 2 \mathrm{H}_{2} \mathrm{O}\end{array}$ & $\begin{array}{l}\text { Compounds bound with oxides } \\
\text { of Fe, Al, and } \mathrm{Mn}\end{array}$ & $\begin{array}{l}\text { Soil : solution }=1: 50,15 \mathrm{~min} \text { on a water bath } \\
\left(85^{\circ} \mathrm{C}\right), 10 \text { min centrifuging }\end{array}$ \\
\hline $0.1 \mathrm{M} \mathrm{NaOH}$ & $\begin{array}{l}\text { Compounds bound with } \\
\text { organic substances }\end{array}$ & $\begin{array}{l}\text { Soil : solution }=1: 50,2 \mathrm{~h} \text { shaking, } 20 \mathrm{~h} \\
\text { extracting, } 10 \text { min centrifuging, washing with } \\
\text { distilled water }\end{array}$ \\
\hline $1 \mathrm{M} \mathrm{HNO}_{3}$ & $\begin{array}{l}\text { Compounds bound to } \\
\text { carbonates and low-solubility } \\
\text { salts }\end{array}$ & $\begin{array}{l}\text { Soil : solution }=1: 50,1 \mathrm{~h} \text { shaking, } 10 \mathrm{~min} \\
\text { centrifuging, washing with distilled water }\end{array}$ \\
\hline Melting with $\mathrm{NaOH}$ & $\begin{array}{l}\text { Compounds in the structure of } \\
\text { soil minerals }\end{array}$ & $\begin{array}{l}\text { Evaporation on a water bath }\left(85^{\circ} \mathrm{C}\right) \text {, solution of } \\
\text { residue in } 1 \mathrm{M} \mathrm{HNO}_{3}\end{array}$ \\
\hline
\end{tabular}

Nonspecifically adsorbed arsenate ions were extracted using $1 \%\left(\mathrm{NH}_{4}\right)_{2} \mathrm{SO}_{4}(\mathrm{pH}$ 6.0-6.2) with addition of ammonium molybdate $\left(1 \%\left(\mathrm{NH}_{4}\right)_{2} \mathrm{SO}_{4}+0.25 \%\left(\mathrm{NH}_{4}\right)_{2} \mathrm{MoO}_{4}, \mathrm{pH}\right.$ 5.5-6.0) to prevent re-precipitation of As into the solution. Specifically adsorbed arsenate ions were extracted with $1 \mathrm{M} \mathrm{NH}_{4} \mathrm{H}_{2} \mathrm{PO}_{4}$. The As compounds retained by oxides of Fe, $\mathrm{Al}$, and $\mathrm{Mn}$ compounds were determined using the Mehra-Jackson extract $\left(0.5 \mathrm{M} \mathrm{Na}_{3} \mathrm{C}_{6} \mathrm{H}_{5} \mathrm{O}_{7}+1 \mathrm{M} \mathrm{NaHCO}_{3}+0.13 \mathrm{M}\right.$ $\mathrm{Na}_{2} \mathrm{~S}_{2} \mathrm{O}_{4} \cdot 2 \mathrm{H}_{2} \mathrm{O}$ with $\mathrm{pH} 7.3$, Table 2). The As-containing compounds bound with organic substances were extracted with $0.1 \mathrm{~N} \mathrm{NaOH}$ and bound to carbonates; low solubility salts were isolated with $1 \mathrm{~N} \mathrm{HNO}_{3}$. Arsenic in the structure of the minerals comprising the soil was represented by residual fractions remaining after extraction was extracted by melting with $\mathrm{NaOH}$. Analyses of As content in the soil extracts were determined by atomic absorption spectrophotometry (AAS, KVANT 2-AT, Kortec Ltd., Russia).

Preparation of samples for cytological and ultrastructural observation

When the $H$. sativum plants reached the boot-and-head emergence phase (day 45 after sowing, Pérez-Harguindeguy et al. 2013), 24 fresh samples were selected for analysis using light optical and electron microscope (2 plants each were taken for 4 treatment variants with 3 replications each). Samples of plants were taken from the central part of the second or third leaf $(2 \times 2 \mathrm{~mm})$ and from the root fibrils $(2 \mathrm{~mm})$. All stages of tissue preparation for morphological analysis were performed using common techniques and included contrasting, dehydration, fixing in a polymerising mixture, and preparation and staining of semi-thin sections for light optical analysis (Fedorenko et al. 2018).

Semi-thin Sect. 0.5-1 $\mu$ m wide were analysed by light optical microscopy using a LOMO microscope (Russia) at magnifications of 100x and 400x. Ultrathin sections were obtained using an ultramicrotome EM UC6 (Leica, Germany) and contrasted with lead citrate. Microscopic analysis was performed using transmission electron microscopy (TEM) Tecnai G2 (Phillips, Netherlands) at the CCU Modern Microscopy of the Southern Federal University (Rostov-on-Don, Russia). 
Ultrastructural measurements were performed using 10 sections from each sample for light optical microscopy and 10 sections for electron microscopy with an automated system for image analysis (Olympus Soft Imaging Solution iTEM).

Morphological characterisation

At the ripening stage (day 80), the remaining plants were harvested for morphological and ultrastructural measurements ( 10 plants were taken from 4 treatment variants with 3 replications each for a total of 120 plants). The following parameters were measured: root length, plant height, stem length, leaf length, spike length, length of the spike with setas, and 1000 grains weight. Next, the plants were divided into stem, roots, and grains for further analysis.

Determination of arsenic in $H$. sativum tissue and its accumulation in the soil-plant system

The plant parts (stems, roots, grains) were dried at $105^{\circ} \mathrm{C}$ for $30 \mathrm{~min}$ and then at $70^{\circ} \mathrm{C}$ to a constant weight to determine dry biomass. The dry biomass was ground to a powder, then ashed in a muffle furnace at $450^{\circ} \mathrm{C}$ for $6 \mathrm{~h}$ dissolved in $5 \mathrm{ml}$ of $20 \% \mathrm{HCl}$, filtered through $0.45 \mu \mathrm{m}$ Whatman filter paper, washed into a 50 -mL flask, and brought to the required volume with deionised water. Mineralisation of the plant samples was carried out according to the Standard Russian method (GOST 26929-94). The toxicity level of As in the $H$. sativum tissues of the plants was determined by comparison with the Standard Russian maximum permissible concentration (MPC) of As in grain and grain products which is $0.2 \mathrm{mg} / \mathrm{kg}$ (Sanitary Regulations and Norms 2.3.2.1078-01). Depending on the As concentration, the standard sample of $H$. sativum obtained from the Federal Agency for Technical Regulation and Metrology of Russian Federation was used for the digestion procedure (standard sample 10-234-2019).

To assess As accumulation in the soil-plant system, the following factors were calculated. The BCF was defined as the ratio of the content of the pollutant in the shoots to the total content in the soil (Edwards et al. 1998) and indicates the degree of 'biophilicity' of the element and any changes (Brooks 1983). If BCF < 1, the barrier functions of the root system manifest. Soil properties include amount of organic matter, texture, CEC, and the effect of speciation of As on its bioavailability to plants (Huang et al. 2006; Zhao et al. 2009; Sharma et al. 2020).

To obtain the soluble As concentration in the soil (BF-soluble), the bioaccumulation factor (BF) was calculated as the ratio of the concentration of As in the plant biomass (roots and aerial parts) to the concentration of soluble As in the soil (Brooks 1998; Brunetti et al. 2012). The first two fractions (specifically and nonspecifically adsorbed As compounds) were used to calculate the BF-soluble factor. The translocation factor (TF) was defined as the ratio between the pollutant content in the shoots and that in the roots (Brunetti et al. 2012; Otones et al. 2011). According to Kachenko and Singh (2006), the TF can be used to quantify existing differences in the bioavailability of pollutants to plants, thus indicating their mobility in the soil.

Statistical analyses

All laboratory tests were performed in triplicate. The results obtained were processed mathematically using Microsoft Excel and STATISTICA v 10 software packages. All the data were presented as the mean values \pm the standard deviation (SD), obtained by applying the post-hoc Tukey's honest significant difference test (HSD, $p \leq 0.05)$.

\section{Results}

Arsenic fractional composition in Haplic Chernozem 
The main proportion of As compounds in unpolluted soil was found in the residual fraction (57\%) characteristic of bonding with silicates (Table 3). The content of the most mobile fractions of As in unpolluted Haplic Chernozem was less than $6 \%$ of the total specifically and nonspecifically adsorbed fractions. The specifically adsorbed fraction of As was higher than the As content in the nonspecifically adsorbed fraction. The amount of As in the fraction bound with organic substances was $7 \%$. The As compounds bound with $\mathrm{Fe}$, Al, and $\mathrm{Mn}$ oxides (29\%) plays an important role in the fixation of As.

Table 3

Fractional distribution of As in soil of the model experiment

\begin{tabular}{|c|c|c|c|c|c|c|c|c|}
\hline \multirow{2}{*}{$\begin{array}{l}\text { Dose of As, } \\
\mathrm{mg} / \mathrm{kg}\end{array}$} & \multirow[t]{2}{*}{ Unit } & \multicolumn{7}{|l|}{ Fractions } \\
\hline & & $\begin{array}{l}\text { nonspecifically } \\
\text { absorbed }\end{array}$ & $\begin{array}{l}\text { specifically } \\
\text { absorbed }\end{array}$ & $\begin{array}{l}\text { bound } \\
\text { with } \\
\text { oxides } \\
\text { of Fe, } \\
\text { Al, } \\
\text { and } \\
\text { Mn }\end{array}$ & $\begin{array}{l}\text { bound with } \\
\text { organic } \\
\text { substances }\end{array}$ & $\begin{array}{l}\text { bound with } \\
\text { carbonates } \\
\text { and not } \\
\text { easily } \\
\text { soluble } \\
\text { salts }\end{array}$ & $\begin{array}{l}\text { in the } \\
\text { structure } \\
\text { of soil } \\
\text { minerals }\end{array}$ & Sum \\
\hline \multirow{2}{*}{$\begin{array}{l}- \\
\text { (unpolluted } \\
\text { soil) }\end{array}$} & $\mathrm{mg} / \mathrm{kg}$ & $0.2 \pm 0.01 *$ & $0.4 \pm 0.03$ & $\begin{array}{l}2.6 \pm \\
0.2\end{array}$ & $0.6 \pm 0.04$ & $0.1 \pm 0.01$ & $5.2 \pm 0.4$ & \multirow[t]{2}{*}{$\begin{array}{l}9.1 \\
\pm 0.9\end{array}$} \\
\hline & $\%$ & 2 & 4 & 29 & 7 & 1 & 57 & \\
\hline \multirow[t]{2}{*}{20} & $\mathrm{mg} / \mathrm{kg}$ & $0.6 \pm 0.04$ & $0.9 \pm 0.1$ & $\begin{array}{l}8.8 \pm \\
0.8\end{array}$ & $1.54 \pm 0.1$ & $0.5 \pm 0.01$ & $\begin{array}{l}15.0 \pm \\
1.0\end{array}$ & \multirow[t]{2}{*}{$\begin{array}{l}27.3 \\
\pm 2.0\end{array}$} \\
\hline & $\%$ & 2 & 3 & 32 & 7 & 1 & 53 & \\
\hline \multirow[t]{2}{*}{50} & $\mathrm{mg} / \mathrm{kg}$ & $1.6 \pm 0.1$ & $3 \pm 0.2$ & $\begin{array}{l}19.5 \pm \\
1.8\end{array}$ & $3.9 \pm 0.3$ & $1.1 \pm 0.1$ & $\begin{array}{l}25.3 \pm \\
2.5\end{array}$ & \multirow[t]{2}{*}{$\begin{array}{l}54.4 \\
\pm 5.1\end{array}$} \\
\hline & $\%$ & 3 & 6 & 36 & 7 & 2 & 47 & \\
\hline \multirow[t]{2}{*}{100} & $\mathrm{mg} / \mathrm{kg}$ & $8.5 \pm 1.7$ & $10.8 \pm 2.2$ & $\begin{array}{l}46.0 \pm \\
10.4\end{array}$ & $11.2 \pm 1.7$ & $3.1 \pm 0.5$ & $\begin{array}{l}26.3 \pm \\
5.4\end{array}$ & \multirow[t]{2}{*}{$\begin{array}{r}106 \\
\pm 13\end{array}$} \\
\hline & $\%$ & 8 & 10 & 43 & 11 & 3 & 25 & \\
\hline
\end{tabular}

The addition of As into soil in various doses increased the content of more mobile nonspecific and specifically-bound As from 3 (2 APC) to 43 folds (10 APC) compared to unpolluted soil. The fraction of As bound with organic substances increased from $7-11 \%$ at very high degree of pollution (10 APC). The proportion of As in Fe, Al, Mn oxides during contamination is up to $36-43 \%$. The fraction of low-solubility As compounds, represented mostly by Fe and Ca arsenates, increased from 1-8\% with increasing of soil pollution (from 2 APC to 10 APC). The portion of As in stable compounds not transferred into extracts reduced the degree of pollution in the structure of the minerals comprising the soil and comprised $47-25 \%$ of the total fraction of the As.

Arsenic accumulation and its distribution in H. sativum

The results showed that the As content in different parts of plants grown in unpolluted soil was $0.01-0.2 \mathrm{mg} / \mathrm{kg}$ (Table 4). A $20 \mathrm{mg} / \mathrm{kg}$ dose of As caused 4, 3, and 2 times higher As content in the roots, stems, and grains, respectively, than in the control plants. The accumulation of metal in the parts of the plants increased as the applied dose increased (Table 4). 
Table 4

Content of As in Hordeum sativum and analyzed indicators

\begin{tabular}{|lllllll|}
\hline \multirow{2}{*}{ Dose of As, $\mathrm{mg} / \mathrm{kg}$} & \multicolumn{4}{c}{ As content in, $\mathrm{mg} / \mathrm{kg}$} & \multicolumn{3}{l|}{ Factors } \\
\cline { 2 - 7 } & root & stem & grain & BCF & BF-soluble & TF \\
\hline- & $0.2 \pm 0.1$ & $0.1 \pm 0.1$ & $0.01 \pm 0.01$ & 0.01 & 0.52 & 0.55 \\
(uncontaminated soil) & & & & & & \\
\hline 20 & $0.7 \pm 0.1$ & $0.3 \pm 0.1$ & $0.02 \pm 0.01$ & 0.01 & 0.68 & 0.46 \\
\hline 50 & $2.7 \pm 0.1$ & $0.7 \pm 0.1$ & $0.10 \pm 0.1$ & 0.01 & 0.75 & 0.29 \\
\hline 100 & $10.3 \pm 1.0$ & $1.9 \pm 0.1$ & $0.36 \pm 0.07$ & 0.02 & 0.65 & 0.22 \\
\hline \pm- the standard deviation (SD) & & & & & \\
\hline
\end{tabular}

The grain of $H$. sativum were contaminated at the highest added dose of As of $100 \mathrm{mg} / \mathrm{kg}$ (MPC for grain $0.2 \mathrm{mg} / \mathrm{kg}$ ). Also, the addition of $100 \mathrm{mg} / \mathrm{kg}$ As to the soil caused the toxicity of the plants to exceed the MPC in plants (0.5 $\mathrm{mg} / \mathrm{kg}$ ) by 5 times.

Assessment of the effect of arsenic on morphological parameters in H. sativum

The total height of $H$. sativum (including the height of the stem from the tillering node and the height of the spike with awns) in the control plants was $85.9 \mathrm{~cm}$ (Table 5). A low dose of As (20 mg/kg) did not affect plant height, roots, stems, or leaf length; however higher doses (50 and $100 \mathrm{mg} / \mathrm{kg}$ of As) caused a high decrease in morphological parameters: the length of the roots decreased by 24 and $58 \%$, the height of the plants by 20 and $42 \%$, the length of the stems by 21 and 40\%, and spike length with awns by 18 and $48 \%$, respectively. At $100 \mathrm{mg} / \mathrm{kg}$, the length of the leaf decreased by $22 \%$ and spike length without awns decreased by $47 \%$. These changes resulted in decreased productivity of $H$. sativum at these doses. The mass of 1000 grains decreased from 21 to $58 \%$ when the dose of As increased from $50 \mathrm{mg} / \mathrm{kg}$ to $100 \mathrm{mg} / \mathrm{kg}$, respectively.

Table 5

Morphological indicators of Hordeum sativum at the ripening stage grown in model experiment conditions

\begin{tabular}{|c|c|c|c|c|c|c|c|}
\hline $\begin{array}{l}\text { Dose of As, } \\
\mathrm{mg} / \mathrm{kg}\end{array}$ & $\begin{array}{l}\text { Root } \\
\text { length, } \\
\mathrm{cm}\end{array}$ & $\begin{array}{l}\text { Plant } \\
\text { height, } \\
\text { cm }\end{array}$ & $\begin{array}{l}\text { Stem } \\
\text { length, } \\
\mathrm{cm}\end{array}$ & $\begin{array}{l}\text { Length of } \\
\text { the leaf, } \\
\mathrm{cm}\end{array}$ & $\begin{array}{l}\text { Spike } \\
\text { length, } \\
\mathrm{cm}\end{array}$ & $\begin{array}{l}\text { Length of the } \\
\text { spike with setas, } \\
\text { cm }\end{array}$ & $\begin{array}{l}1000 \\
\text { grains } \\
\text { weight, } g\end{array}$ \\
\hline $\begin{array}{l}\text { - } \\
\text { (uncontaminated } \\
\text { soil) }\end{array}$ & $\begin{array}{l}33.1 \pm \\
1.7\end{array}$ & $\begin{array}{l}85.9 \pm \\
4.0\end{array}$ & $\begin{array}{l}69.0 \pm \\
3.5\end{array}$ & $21.6 \pm 1.4$ & $\begin{array}{l}5.5 \pm \\
0.4\end{array}$ & $16.9 \pm 1.5$ & $23.8 \pm 1.2$ \\
\hline 20 & $\begin{array}{l}34.3 \pm \\
2.2\end{array}$ & $\begin{array}{l}78.9 \pm \\
2.9\end{array}$ & $\begin{array}{l}65.9 \pm \\
3.5\end{array}$ & $20.1 \pm 1.7$ & $\begin{array}{l}5.9 \pm \\
0.5\end{array}$ & $13.0 \pm 1.1$ & $22.9 \pm 2.0$ \\
\hline 50 & $\begin{array}{l}25.1 \pm \\
2.5\end{array}$ & $\begin{array}{l}68.6 \pm \\
4.0\end{array}$ & $\begin{array}{l}54.8 \pm \\
3.3\end{array}$ & $19.0 \pm 1.2$ & $\begin{array}{l}4.7 \pm \\
0.6\end{array}$ & $13.8 \pm 1.3$ & $18.8 \pm 1.8$ \\
\hline 100 & $\begin{array}{l}14.0 \pm \\
1.3\end{array}$ & $\begin{array}{l}50.1 \pm \\
3.0\end{array}$ & $\begin{array}{l}41.3 \pm \\
2.5\end{array}$ & $16.8 \pm 1.4$ & $\begin{array}{l}2.9 \pm \\
0.2\end{array}$ & $8.8 \pm 0.8$ & $10.0 \pm 0.9$ \\
\hline
\end{tabular}

Light-optical microscopy of $H$. sativum tissues affected by arsenic 
Light-optical microscopic observations of $H$. sativum tissues showed sparse and shorten root hairs, smaller central cylinder than the in the control (Fig. 1, Table 6). A change in the structure of the conductive tissue in the central cylinder was observed. The central cylinder had one large vessel in the center and many small radially-located vessels, and separated from the cortex by the endoderm which consisted of a single layer of cells and included the xylem vessels and phloem sieve tubes that form the conductive tissues. (Fig. 1). Most of the root cross-section (up to 70\%) was primary bark (Table 6). Exposure to As at concentrations of 20,50, and $100 \mathrm{mg} / \mathrm{kg}$ inhibited development of the epiblema, and the bark layer was thin, comprising less than $50 \%$ of the cross-section area of the root. A layer of large cells of water-storage tissue was located under the epidermis of leaf cells. Mesophyll with a system of intercellular spaces and conductive bundles (the number determines the rate of water uptake by the leaf plate) was located between the lower and upper epidermis. The spongy parenchyma was characterised by a large number of intercellular spaces that facilitate gas exchange. Whereas, the leaves of the control plants were covered with a single epidermal layer of closely connected cells, the outer walls of which were covered with cuticles (Fig. 2).

Table 6

Quantitative ultrastructural analysis of cytologic characteristics of root and leaf plate tissue cells of Hordeum sativum grown in soil polluted with As

\begin{tabular}{|c|c|c|c|c|c|c|}
\hline $\begin{array}{l}\text { Experiment } \\
\text { sample }\end{array}$ & $\begin{array}{l}\text { Cross- } \\
\text { sectional } \\
\text { area } \\
\text { of the } \\
\text { cortex, } \\
\mu^{2}\end{array}$ & $\begin{array}{l}\text { Average cell } \\
\text { size of the } \\
\text { cortex, } \\
\mu^{2}\end{array}$ & $\begin{array}{l}\text { Cross- } \\
\text { sectional } \\
\text { area } \\
\text { of the } \\
\text { central } \\
\text { cylinder, } \\
\mu^{2}\end{array}$ & $\begin{array}{l}\text { The average } \\
\text { number of } \\
\text { cells per } 1 \mathrm{~mm}^{2} \\
\text { of the } \\
\text { chlorenchyma }\end{array}$ & $\begin{array}{l}\text { Average cell size, } \\
\mu m^{2} \text { of the } \\
\text { chlorenchyma }\end{array}$ & $\begin{array}{l}\text { Number of } \\
\text { plastids } \\
\text { per } \\
\text { cell }\end{array}$ \\
\hline \multirow[t]{2}{*}{ Control } & 74315 & 268 & 13441 & 4528 & 146 & 7.4 \\
\hline & \pm 2229 & \pm 20 & \pm 403 & \pm 127 & \pm 9 & \pm 0.3 \\
\hline \multirow{2}{*}{$\begin{array}{l}20 \mathrm{mg} / \mathrm{kg} \\
\text { of As }\end{array}$} & 28793 & $252 \pm 37$ & 13017 & $4372 \pm 297$ & $151 \pm 13$ & $7.1 \pm 0.6$ \\
\hline & \pm 1697 & & \pm 396 & & & \\
\hline \multirow{2}{*}{$\begin{array}{l}50 \mathrm{mg} / \mathrm{kg} \\
\text { of As }\end{array}$} & 24627 & $247 \pm 29$ & 12627 & $4107 \pm 248$ & $154 \pm 16$ & $6.8 \pm 0.7$ \\
\hline & \pm 1453 & & \pm 468 & & & \\
\hline \multirow{2}{*}{$\begin{array}{l}100 \mathrm{mg} / \mathrm{kg} \\
\text { of As }\end{array}$} & 16596 & 226 & 12192 & 3706 & 167 & 6.1 \\
\hline & \pm 581 & \pm 24 & \pm 427 & \pm 198 & \pm 12 & \pm 0.2 \\
\hline
\end{tabular}

The pollutant violated the integrity of the epidermis, especially in the lower layer and reduced the number of mesophyll cells (from 4528 cells $/ \mathrm{mm}^{2}$ in the control plants to $3705 \pm 198$ cells $/ \mathrm{mm}^{2}$ in plants contaminated with contamination $100 \mathrm{mg} / \mathrm{kg}$ of As, Table 6).

Ultrastructural changes in the cells of roots and leaves of $H$. sativum

The results of TEM studies revealed changes in the ultrastructure of roots and leaves of $H$. sativum. Dense flattened cytoplasm adjacent to the cell wall was filled with free ribosomes (Figs. 3a, c, e). Vacuole occupies the most area within the cell. Endoplasmic reticulum (EPR) and Golgi apparatus were not sufficiently developed. The EPR was represented by short cisterns, randomly scattered along the cell section, some of which were associated with 
ribosomes. Round mitochondria with a small number of slightly extended flattened cristae contained a relatively electron-light matrix. Dictyosomes contained small stacks of cisternae without expressed polarisation. The round or slightly lobed nucleus occupied a large volume of the cell.

In the roots of plants grown in the highly-high polluted soil, cytoplasm with a low ribosome count was highly vacuolated (Figs. 3b, d, f). Swollen drop-shaped cristae were found in mitochondria on a background matrix with high electron density (Fig. 3f). Single cytoplasmic fragments were observed in the central vacuole due to violation of the integrity of the cell membrane (Fig. 3b). Ultrastructural changes in single cells were destructive (Fig. 3d).

Most of the chlorenchyma leaf cells of the control plants were elliptical or round in shape. The cytoplasm contained the nucleus, plastids, mitochondria, ribosomes, and other organelles in the form of a narrow strip adjoining the cell wall (Figs. 4a, 4c, 4e). The middle part of the cell section area was occupied by a large vacuole containing groups of small particles. Chloroplasts were elliptically shaped with a dense matrix. The system of internal membranes (lamellae) in the organelles was represented by single stromal thylakoids and densely-grouped grana of thylakoids. The number of lamellae in a granum varied from 2-3 to 20-30 units (Fig. 4c, insertion) and the majority of these were in plastid and large. Free single ribosomes were scattered in a narrow strip of cytoplasm tightly adjacent to the plastid, and a few dense $80 \mathrm{~nm}$ plastoglobules formed small groups of 2-3 units. Oval mitochondria (about $0.6 \mu \mathrm{m}$ in diameter) contained a moderately-dense matrix with evenly distributed slightly swollen cristae (Fig. 4e). Peroxisomes contained a fine-grained homogeneous matrix with diameters of about $1 \mu \mathrm{m}$ (Fig. 4e).

A decrease in the electron density of the stroma was observed in the plastids of plants grown in polluted soil. Small grains with 2 to 5 lamellae increased in length and the inner thylakoid space expanded (Fig. 4d). The number of plastoglobules also increased. Large, elongated mitochondria, up to $2 \mu \mathrm{m}$ in size, contained a light matrix and numerous swollen cristae appeared. In some cells, significant vacuolisation of the cytoplasm was observed as well as numerous agglomerations of condensed high-density nuclear chromatin evenly distributed over the entire surface of the organelle (Fig. 4f, g).

\section{Discussion}

The distribution of As was determined for the types of compounds found in the unpolluted Haplic Chernozem (Table 3) as follows (in descending order): As compounds within the structure of the minerals comprising the soil > compounds bound with $\mathrm{Fe}, \mathrm{Al}$, and $\mathrm{Mn}$ oxides > bound with organic substances $>$ specifically adsorbed > nonspecifically adsorbed $>$ bound with carbonates and low-solubility salts.

In present findings, the main proportion of As compounds in unpolluted soil was found in the residual fraction characteristic of bonding with silicates. The presence of As in various minerals determines its content in various rocks (Price and Pichler, 2006; Kabata-Pendias and Mukherjee 2007; Tabelin et al., 2018; Mensah et al. 2020). The source of the As, as well as other chemical elements in the unpolluted soil, was pedogenic minerals. Compounds of As, presumably bound with carbonates and low-solubility arsenates, were practically absent in Haplic Chernozem.

Despite the high humus content in the soil studied, As mostly formed compounds with $\mathrm{Fe}, \mathrm{Al}$, and Mn oxides. The absorption of As by soils depends on the content of amorphous Fe oxides. In contrast to crystalline structures, As is adsorbed on to the outer surface of crystals or enters the loose and highly hydrated structure (Smith et al. 1999; Mensah et al. 2020).

Moreover, the studied Haplic Chernozem was characterised by $\mathrm{C}$ weak alkaline reactions in a medium that caused coprecipitation of arsenate ions by Fe and Al oxides and increased the As concentration in the soil. The correlation

Page $10 / 20$ 
coefficients between the sorption parameters of $A s(V)$ in some soils and the content of weakly-crystallised nonsilicate Fe compounds $(R=0.80)$ reveals their interdependence (Smith et al. 1999). The arsenate ions were able to establish covalent bonds with the cations to form readily-soluble salts. The trend of decreasing of As content compounds in the structure of soil minerals indicates that increased mobility of As compounds in soil is related to the increase in the amount of specifically adsorbed and nonspecifically adsorbed forms of the element.

Distribution of As in soil fractions under contamination (concentrations of 20 and $50 \mathrm{mg} / \mathrm{kg}$ ) was similar to its distribution in unpolluted soil; however, soil polluted with As in concentrations of $100 \mathrm{mg} / \mathrm{kg}$ re-distributed the fractional composition characterised by a predominance of compounds bound with $F e, A 1$, and Mn oxides as follows (in descending order): As bound with $\mathrm{Fe}, \mathrm{Al}$, and $\mathrm{Mn}$ oxides $>$ As compounds in the structure of soil minerals $>$ As bound with organic substances $>$ specifically adsorbed As $>$ nonspecifically adsorbed As $>$ As bound with carbonates and low-solubility salts.

Changes in the fractional composition of As in polluted soil and first of all in mobile forms (nonspecific and specifically-bound As) were reflected in its accumulation in plants. Excess of the permissible level of As contamination was detected at a contamination dose of $100 \mathrm{mg} / \mathrm{kg}$.

The intensity of As accumulation by $H$. sativum grown in unpolluted soil (control) was very low $(\mathrm{BCF}=0.01)$. With an increase in As contamination, the BCF factor did not changed, indicating the barrier functions of the root system. BCF factor was getting higher only at the highest level of pollution (up to 0.02). BF-soluble factor increased with the degree of soil contamination, indicating that unhindered flow of metalloids from soil into plants. However, the highest level of soil pollution caused a decrease in the BF-soluble factor.

The $H$. sativum grown in unpolluted soil (control) and in the variant with $20 \mathrm{mg} / \mathrm{kg}$ of As were characterised by high TF values ( $<0.55$ and $<0.46$, respectively). There is a decrease in the TF factor with an increase in the level of pollution, the value of TF was 0.22 under the highest treatment dose. This regularity shows the role of the root/stem barrier function in case of contamination.

. A low dose of As (20 mg/kg) did not affect on plants and higher doses (50 and $100 \mathrm{mg} / \mathrm{kg}$ of As) caused a high decrease in morphological parameters. Structural and ultrastructural examination of $H$. sativum tissues using light and TEM showed effects on changes in cellular organelles. However, there were no qualitative changes in the ultrastructure of plant cells at doses of 20 and $50 \mathrm{mg} / \mathrm{kg}$ of As, and differences in the morphometric parameters of intermediate doses were not all significant. The toxic effects of metals on ultrastructural indices were also noted in recent finding on $H$. sativum anatomy, however, it was less expressed (Rajput et al. 2018; Minkina et al. 2020). The toxic effects of $\mathrm{Cr}$, Ni, and $\mathrm{Zn}$ on Typha domingensis macrophytes increased the root cross-sectional area of the stele (Hadad et al. 2010). Thus, it appears that structural changes in the root determine transport characteristics (capabilities) allow the plant to adapt to unfavourable environmental conditions in its habitat. The structure of the vascular bundle changed, and the division of the mesophyll into spongy and columnar parenchyma was poorly traced. The average size of chlorenchyma cells increased from $145 \mu \mathrm{m}^{2}$ in the control plants to $167 \mu \mathrm{m}^{2}$ in plants contaminated by $100 \mathrm{mg} / \mathrm{kg}$ of As. The number of plastids per cell decreased from 7.4 to 6.1. Plant samples grown in soil contaminated with 20 and $50 \mathrm{mg} / \mathrm{kg}$ of As had morphometric parameters similar to those observed in the control plants.

Data from ultrastructural analysis of plant cells grown at a contamination dose of $100 \mathrm{mg} / \mathrm{kg}$ were the most informative and significant. The micrographs show that the ultrastructure of the root cells in the control plants is similar to data obtained in previous studies (Fedorenko et al. 2020a; Fedorenko et al. 2020b). Similar changes in the ultrastructure of root cells were observed in Typha angustifolia under the toxic influence of $\mathrm{Pb}\left(\mathrm{NO}_{3}\right)_{2}(20,000 \mathrm{mg} / \mathrm{L})$ 
with partial degradation of the cell wall of the root parenchyma (Panich-pat et al. 2005). After treatment of $T$. angustifolia seedlings with $\mathrm{Cr}, \mathrm{Cd}$, and $\mathrm{Pb}$, destructive changes in cytoplasmic membranes, mitochondria, and cell vacuoles were observed in the roots (Mohamed and Huaxin 2015). In addition, disorganisation of the thylakoid system and vacuolisation of chloroplasts were observed in the leaves of these plants. Based on these results, it can be concluded that these types of structural changes are adaptive and that homeostatic mechanisms enable the plant to resist (tolerate) pollution.

Photosynthesis is the fundamental function of plants, and the structures in the leaves are determined to photosynthetic activity. A decrease in the number of lamellae in the grana and a more homogenous distribution over the entire area of the chloroplast section optimises conditions for contact of the thylakoid surface with the environment, providing enhanced 'pumping' of protons from the stroma $(\mathrm{pH} 8)$ into the inner thylakoid space $(\mathrm{pH} \approx 5)$. This may create an additional proton-driving force against the thylakoid membrane, and as a result, the membrane syntax of ATP will synthesise the amount of ATP (Hinkle and McCarty 1978) required to supply cells with energy to function under extreme factors. It was an evident that the change in donor-acceptor relations resulting from transformation of the thylakoid system of plastids may control the mechanism of plant adaptation to adverse environmental conditions (Klimov et al. 1990). The spatial rearrangement of the internal plastid membranes probably indicates functional activation of a modified thylakoid system.

At the same time, an increase in the number of plastoglobules probably occurred due to changes in the membrane structure of the plastids because the constituent components of the photosynthetic membranes such as lipids, proteins, and pigments released during the rearrangement of grana accumulate directly in plastoglobules (Guiamet et al. 1999; Titov et al. 2007).

\section{Conclusions}

The pattern of formation of the fractional composition of As at different concentrations in Haplic Chernozem was studied using three different concentrations and a control group of plants. The largest amount of As was concentrated in the residual fraction. Oxides of $\mathrm{Fe}, \mathrm{Al}$, and $\mathrm{Mn}$ played a key role in the behaviour in the soil samples. The fractional composition of As was significant changed in polluted soil compared to the control soil. The main change occurred in the content of nonspecifically and specifically adsorbed arsenate ions, the proportion of which increased noticeably. At the same time, the residual fraction decreased as the degree of pollution increased.

Despite soil high buffering capacity, the application of high doses of As led to its accumulation in the tissues of the $H$. sativum and adversely affected the morphological and ultrastructural parameters of the plants. The introduction of As at a concentration of $100 \mathrm{mg} / \mathrm{kg}$ had a strong toxic effect associated with high accumulation of the metal in the roots and aboveground parts of the plants Microscopic analysis of the plants revealed destructive changes in the cells of the bark layer of the root and a reduction in the size of the chlorophyllic parenchyma in the leaves. Ultrastructural analysis revealed changes in the main cellular organelles (chloroplasts, mitochondria, and peroxisomes). In conclusion, the behaviour of As in a soil-plant system is important to understand to evaluate its entry into the food chain and potential risk to human health.

\section{Declarations}

\section{Acknowledgment}

This research was supported by the Russian Science Foundation, project no. 19-74-00085.

Page $12 / 20$ 
Credit Author Statement M.B.: Data curation, Formal analysis, Methodology, Investigation, Conceptualization, Supervision, Visualization, Writing - original draft preparation - review \& editing. T.M.: Conceptualization, Supervision, Writing - review \& editing. A.F.: Investigation, Data curation, Visualization, Formal analysis, Writing - review \& editing, Methodology. G.F.: Conceptualization, Supervision. N.C.: Data curation, Methodology, Visualization, Conceptualization, Supervision, Writing - review \& editing. V.D.R.: Data curation, Methodology, Conceptualization, Supervision, Writing review \& editing. S.M.: Formal analysis, Methodology, Writing - review \& editing. T.B.: Conceptualization, Supervision.

Conflicts of interest/Competing interests Authors declare that they have no conflict of interest.

Code availability Not applicable.

Ethics approval and consent to participate Not applicable.

Consent for publication Not applicable.

Consent to participate Not applicable.

\section{References}

Adamo P, lavazzo P, Albanese S, Agrelli, D, De Vivo B, Lima A (2014) Bioavailability and soil-to-plant transfer factors as indicators of potentially toxic element contamination in agricultural soils. Sci Total Environ 500:11-22 https://doi.org/10.1016/j.scitotenv.2014.08.085

Antoniadis V, Levizou E, Shaheen SM, Ok YS, Sebastian A, Baum C, Prasad MNV, Wenzel WW, Rinklebe J (2017) Trace elements in the soil-plant interface: Phytoavailability, translocation, and phytoremediation-A Review. Earth-Science Reviews 171:621-645. https://doi.org/10.1016/j.earscirev.2017.06.005

Arendt EK, Zannini E (2013) Cereal grains for the food and beverage industries, Woodhead Publishing Limited, Elsevier, Oxford, Cambridge, Philadelphia, New Delhi, 512 p

Bowen HJM (1979) Environmental chemistry of the elements, Academic Press, London, 333 p

Brooks RR (1998) Plants that Hyperaccumulate Heavy Metals: Their Role in Phytoremediation, Microbiology, Archaeology. Mineral Exploration and Phytomining, CAB International, Wallingford, $380 \mathrm{p}$

Brooks RR (1983) Biological methods of prospecting for minerals, Wiley, $322 \mathrm{p}$

Brunetti G, Farrag K, Soler-Rovira P, Ferrara M, Nigro F, Senesi N (2012) Heavy metals accumulation and distribution in durum wheat and barley grown in contaminated soils under Mediterranean field conditions. J of Plant Interact 7:160174 https://doi.org/10.1080/17429145.2011.603438

Bundschuh J, Litter MI, Parvez F, Román-Ross G, Nicolli HB, Jean JS, Liu CW, López D, Armienta MA, Guilherme LRG, Cuevas AG (2012) One century of As exposure in Latin America: a review of history and occurrence from 14 countries. Sci Total Environ 429:2-35 https://doi.org/10.1016/j.scitotenv.2011.06.024

Edwards SC, MacLeod CL, Lester JN (1998) The bioavailability of copper and mercury to the common nettle (Urtica dioica) and the earthworm Eisenia fetida from contaminated dredge spoil. Water, Air, Soil Pollut 102:75-90 https://doi.org/10.1023/A:1004993912639 
Fedorenko GM, Fedorenko AG, Minkina TM, Mandzhieva SS, Rajput VD, Usatov AV, Sushkova SN (2018) Method for hydrophytic plant sample preparation for light and electron microscopy (studies on Phragmites australis Cav.) MethodsX 5:1213-1220 https://doi.org/10.1016/j.mex.2018.09.009

Fedorenko AG, Minkina TM, Chernikova NP, Fedorenko GM, Mandzhieva SS, Rajput VD, Burachevskaya MV, Chaplygin VA, Bauer TV, Sushkova SN, Soldatov AV (2020a) The toxic effect of CuO of different dispersion degrees on the structure and ultrastructure of spring barley cells (Hordeum sativum distichum). Environ Geochem Health 1-15 https://doi.org/10.1007/s10653-020-00530-5

Fedorenko AG, Chernikova N, Minkina T, Sushkova S, Dudnikova T, Antonenko E, Fedorenko G, Bauer T, Mandzhieva S, Barbashev A (2020b) Effects of benzo[a]pyrene toxicity on morphology and ultrastructure of Hordeum sativum. Environ Geochem Health 1-12 https://doi.org/10.1007/s10653-020-00647-7

GN 2.1.7.2511/09 (2009) Approximate permissible concentrations (APC) of chemicals in soil, Hygiene standards, Rospotrebnadzor, Moscow [In Russian]

GOST 26929-94 (1994) Raw materials and food products. Sample preparation. Mineralization to determine the content of toxic elements, Moscow [In Russian]

Guiamet JJ, Pichersky E, Nooden LD, (1999) Mass exodus from senescing soybean chioroplasts. Plant Cell Physiol 40:986-992 https://doi.org/10.1093/oxfordjournals.pcp.a029632

Hadad HR, Mufarrege MM, Pinciroli M, Di Luca GA, Maine MA (2010) Morphological response of Typha domingensis to an industrial effluent containing heavy metals in a constructed wetland. Arch Environ Contam Toxicol 58:666-675 https://doi.org/10.1007/s00244-009-9454-0

Hinkle PC, McCarty RE (1978) How cell make ATP. Sci Am 238:104-123

Huang RQ, Gao SF, Wang WL, Staunton S, Wang G (2006) Soil As availability and the transfer of soil As to crops in suburban areas in Fujian Province, southeast China. Sci Total Environ 368:531-541

https://doi.org/10.1016/j.scitotenv.2006.03.013

ISO 18400-104 (2018) Soil quality - Sampling. Part 104: Strategies, 2018.IUSS Working Group WRB, 2015. World reference base of soil resources 2014, update 2015 international soil classification system for naming soils and creating legends for soil maps. World Soil Resources Reports no. 106, FAO, Rome

Jackson ML (1960) Oxidizable matter by chromic acid with H2SO4 heat of dilution. Soil Chemical Analysis, 2nd ed., Prentice Hall, Inc., Englewood Cliffs, NJ, 521 p

Kabata-Pendias A, Mukherjee AB (2007) Trace elements from soil to human. Springer Science \& Business Media, Berlin, Heidelberg, New York, 550 p

Kachenko AG, Singh B (2006) Heavy metals contamination in vegetables grown in urban and metal smelter contaminated sites in Australia. Water, Air, Soil Pollut 169:101-123 https://doi.org/10.1007/s11270-006-2027-1

Klimov TI, Trunova AT, Mironova IA (1990) Adaptive mechanisms of the plants to adverse environmental factors through the change of donor-acceptor relations. Plant Physiol 37:1024-1044 [In Russian] 
Ma L, Wang L, Tang J, Yang Z (2017) As speciation and heavy metal distribution in polished rice grown in Guangdong Province, Southern China. Food Chem 233:110-116 https://doi.org/10.1016/j.foodchem.2017.04.097

Mathee A, Kootbodien T, Kapwata T, Naicker N (2018) Concentrations of As and lead in residential garden soil from four Johannesburg neighborhoods. Environ Res 167:524-527 https://doi.org/10.1016/j.envres.2018.08.012

Matschullat J (2000) As in the geosphere-a review. Sci Total Environ 249:297-312 https://doi.org/10.1016/S00489697(99)00524-0

Matera V, Le Hecho I, Laboudigue A, Thomas P, Tellier S, Astruc M (2003) A methodological approach for the identification of As bearing phases in polluted soils. Environ Pollut 126:51-64 https://doi.org/10.1016/S02697491(03)00146-5

Mensah AK, Marschner B, Shaheen SM, Wang J, Wang S-L, Rinklebe J (2020) Arsenic contamination in abandoned and active gold mine spoils in Ghana: Geochemical fractionation, speciation, and assessment of the potential human health risk. Environ Pollut 261:114116

Minkina TM, Linnik VG, Nevidomskaya DG, Bauer TV, Mandzhieva SS, Khoroshavin VY (2018) Forms of Cu (II), Zn (II), and $\mathrm{Pb}$ (II) compounds in technogenically transformed soils adjacent to the Karabashmed copper smelter. J Soils Sediments 18:2217-2228 https://doi.org/10.1007/s11368-017-1708-2

Minkina T, Rajput V, Fedorenko G, Fedorenko A, Mandzhieva S, Sushkova S, Yao J (2020) Anatomical and ultrastructural responses of Hordeum sativum to the soil spiked by copper. Environ Geochem Health 42:45-58 https://doi.org/10.1007/s10653-019-00269-8

Mohamed BA, Huaxin D (2015) Effects of $\mathrm{Cr}$, Cd, and Pb on ultrastructure, GSH and free cysteine in Typha angustifolia. Transcriptomics 3:1-5 https://doi.org/10.4172/2329-8936.1000115

Motuzov GV, Aptikaev RS, Karpova EA (2006) Fractionation of soil As compounds. Eurasian Soil Sci 39:387-396 https://doi.org/10.1134/S1064229306040053

Nriagu JO, Azcue JM (1994) As in the environment. Part I: cycling and characterization, John Wiley \& Sons, New York, $448 \mathrm{p}$

Oberoi S, Devleesschauwer B, Gibb HJ, Barchowsky A (2019) Global burden of cancer and coronary heart disease resulting from dietary exposure to As, 2015. Environ Res 171: 185-192 https://doi.org/10.1016/j.envres.2019.01.025

Otones V, Álvarez-Ayuso E, García-Sánchez A, Santa Regina I, Murciego A (2011). As distribution in soils and plants of an As impacted former mining area. Environ Pollut 159:2637-2647 https://doi.org/10.1016/j.envpol.2011.05.027

Palma-Lara I, Martínez-Castillo M, Quintana-Pérez JC, Arellano-Mendoza MG, Tamay-Cach F, Valenzuela-Limón OL, García-Montalvo EA, Hernández-Zavala A (2020) As exposure: A public health problem leading to several cancers. Regul Toxicol Pharmacol 110: 104539 https://doi.org/10.1016/j.yrtph.2019.104539

Pandey N, Bhatt R (2016) Role of soil associated Exiguobacterium in reducing As toxicity and promoting plant growth in Vigna radiata. Eur J Soil Biol 75:142-150 https://doi.org/10.1016/j.ejsobi.2016.05.007

Panich-pat T, Srinives P, Kruatrachue M, Pokethitiyook P, Upatham S, Lanza GR (2005) Electron microscopic studies on localization of lead in organs of Typha angustifolia grown on contaminated soil. Science Asia 31:49-53

Page $15 / 20$ 
Pérez-Harguindeguy N, Dıe'az S, Garnier E, Lavorel S, Poorter H, Jaureguiberry P, Bret-Harte M, Cornwell WK, Craine J, Gurvich DE, Urcelay C, Veneklaas E, Reich P, Poorter L, Wright I, Ray P, Enrico L, Pausas JG, Vos A, Buchmann N, Funes G, Quétier F, Hodgson JG, Thompson K, Morgan HD, Steege H, Heijden MVD, Sack L, Blonder B, Poschlod P, Vaieretti MV, Conti G, Staver A, Aquino S, Cornelissenet JC (2013) New handbook for standardised measurement of plant functional traits worldwide. Aust J Bot 61:167-234 https://doi.org/10.1071/BT12225

.Price RE, Pichler T (2006) Abundance and mineralogical association of arsenic in the Suwannee Limestone (Florida): Implications for arsenic release during water-rock interaction. Chem Geol 228:44-56

Rahman MA, Hasegawa H, Rahman MM, Rahman MA, Rahman MA, Miah MAM (2007) Accumulation of arsenic in tissues of rice plant (Oryza sativa L.) and its distribution in fractions of rice grain. Chemosphere 69:942-948

Rajput VD, Minkina T, Fedorenko A, Fedorenko G, Mandzhieva S, Sushkova S, Chernikova N, Duplii N, Azarov A, Usatov A (2018) Interaction of CuO nanoparticles with Hordeum Sativum Distichum in an aquatic medium and in the soil. In Conference of the Arabian J Geosci Springer Cham pp 25-27 https://doi.org/10.1007/978-3-030-01665-4_6

Rajput V, Minkina T, Sushkova S, Behal A, Maksimov A, Blicharska E, Ghazaryan K, Movsesyan H, Barsova N (2020) $\mathrm{ZnO}$ and $\mathrm{CuO}$ nanoparticles: A threat to soil organisms, plants, and human health. Environ Geochem Health 42:147158 https://doi.org/10.1007/s10653-019-00317-3

Sanitary Regulations and Norms 2.3.2.1078-01 (2002) Hygienic requirements for safety and nutritional value of food products, Publishing House of the Siberian Cedar Foundation, Novosibirsk, 180 p [In Russian]

Sharma S, Kumar R, Sahoo PK, Mittal S (2020) Geochemical relationship and translocation mechanism of As in rice plants: A case study from health prone south west Punjab, India. Groundwater sustainable dev 10:100333. https://doi.org/10.1016/j.gsd.2020.100333.

Shein EV (2009) The particle-size distribution in soils. Problems of the methods of study, interpretation of the results, and classification. Eurasian Soil Sci 42:284-291 https://doi.org/10.1134/S1064229309030053

Smith E, Naidu R, Alston AM (1998) As in the soil environment: A review. Adv Agron 64:149-195 https://doi.org/10.1016/S0065-2113(08)60504-0

Smith E, Naidu R, Alston AM (1999) Chemistry of As in soils: I. Sorption of arsenate and arsenite by four Australian soils. J Environ Qual 28:1719-1726. https://doi.org/10.2134/jeq1999.00472425002800060005x

Tabelin CB, Igarashi T, Villacorte-Tabelin M, Park I, Opiso EM, Ito M, Hiroyoshi N (2018) Arsenic, selenium, boron, lead, cadmium, copper, and zinc in naturally contaminated rocks: A review of their sources, modes of enrichment, mechanisms of release, and mitigation strategies. Sci Total Environ 645:1522-1553

Tan KH (1996) Soil Sampling, Preparation and Analysis, Marcel Dekker Inc, New York, 672 p

Taylor SR, McLennan SM (1985) The continental crust: its composition and evolution. Blackwell Scientific Publication, Oxford, $312 \mathrm{p}$

Tessier A, Campbell P, Bisson M (1979) Sequential extraction procedure for the speciation of particulate trace metals. Anal Chem 51:844-850. https://doi.org/10.1021/ac50043a017 
Titov AF, Akimova TV, Venzhik YuV (2007) Effect of root heating on the tolerance of barley leaf cells and ultrastructure of chloroplasts and mitochondria. Dokl Biol Sci 415:324-327 https://doi.org/10.1134/S0012496607040229

Tong J, Guo H, Wei C (2014) As contamination of the soil-wheat system irrigated with high As groundwater in the Hetao Basin, Inner Mongolia, China. Sci Total Environ 496:479-487 https://doi.org/10.1016/j.scitotenv.2014.07.073

Tu S, Ma LQ (2003) Interactive effects of $\mathrm{pH}$, As and phosphorus on uptake of As and $\mathrm{P}$ and growth of the As hyperaccumulator Pteris vittata L. under hydroponic conditions. Environ Exp Bot 50:243-251 https://doi.org/10.1016/S0098-8472(03)00040-6

Ure AM, Quevauviller PH, Muntau H, Griepink B (1993) Speciation of heavy metals in soils and sediments. An account of the improvement and harmonization of extraction techniques undertaken under the auspices of the BCR of the Commission of the European Communities. Int J Environ Anal Chem 51:135-151.

https://doi.org/10.1080/03067319308027619

Vorob'eva LA (2006) Theory and practice of the chemical analysis of soils. GEOS, Moscow, 401 p [in Russian]

Warren GP, Alloway BJ, Lepp NW, Singh B, Bochereau FJM, Penny C (2003) Field trials to assess the uptake of As by vegetables from contaminated soils and soil remediation with iron oxides. Sci Total Environ 311:19-33

https://doi.org/10.1016/S0048-9697(03)00096-2

Zhao F-J, Ma JF, Meharg AA, McGrath SP (2009) As uptake and metabolism in plants. New Phytol 181:777-794 https://doi.org/10.1111/j.1469-8137.2008.02716.x

Zhao F-J, Wang P (2020) Arsenic and cadmium accumulation in rice and mitigation strategies. Plant Soil 446:1-21 https://doi.org/10.1007/s11104-019-04374-6

\section{Figures}



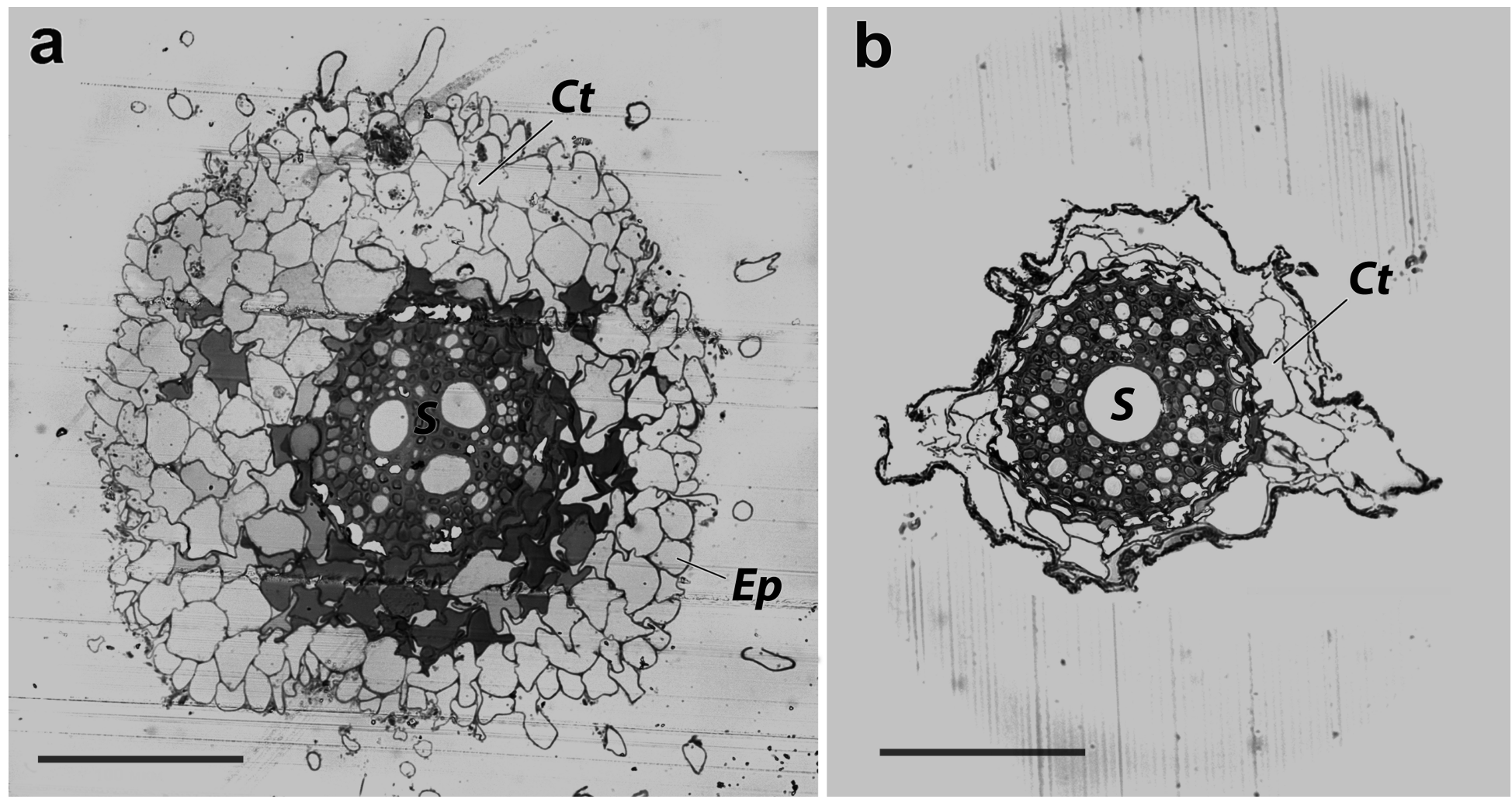

Figure 1

Cross-section of a root: a) control plant, b) polluted plant, Ep = epidermal cells, $\mathrm{Ct}=$ cortex, $\mathrm{S}=$ central cylinder (stele). The scale bar is $100 \mu \mathrm{m}$.
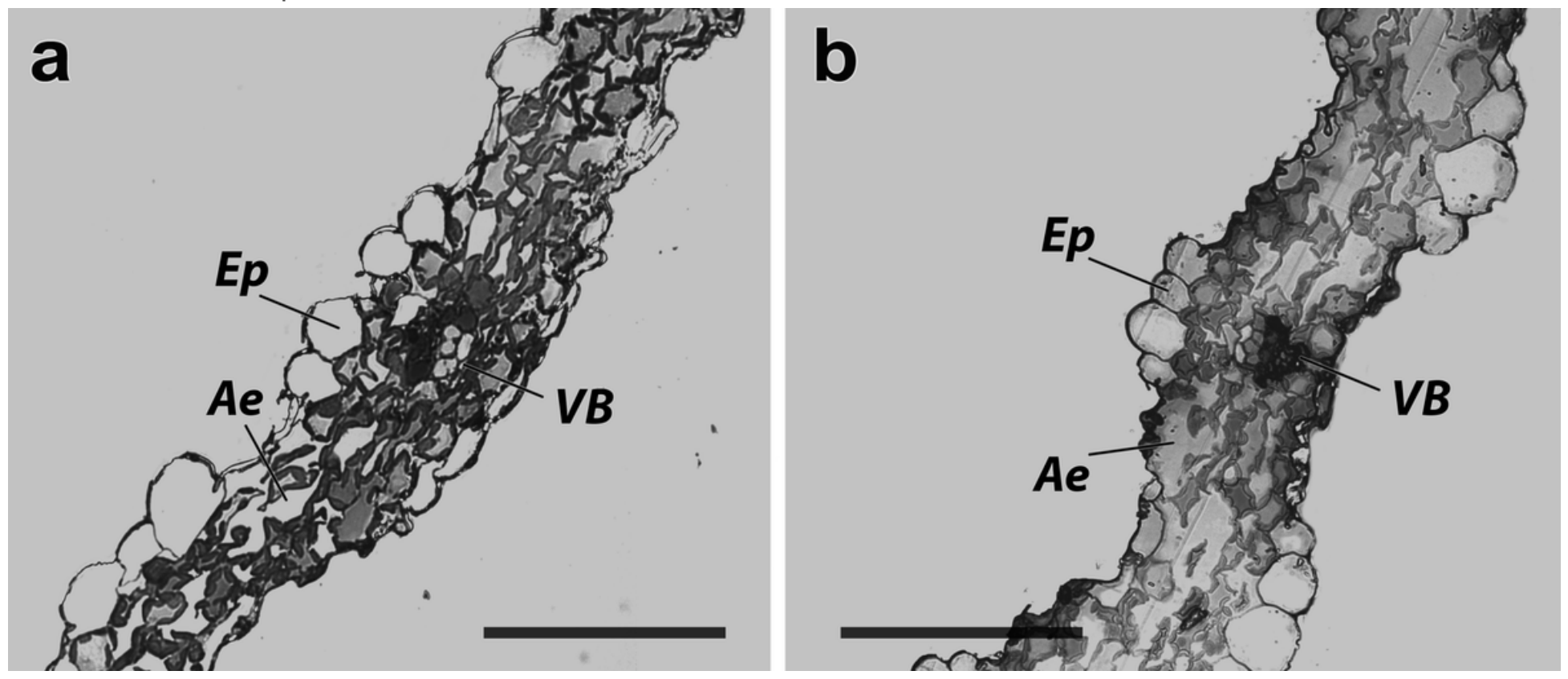

Figure 2

Cross-section of a leaf: a) control plant, b) polluted plant, $\mathrm{Ep}=$ epidermal cells, $\mathrm{Me}=$ mesophyll, $\mathrm{Ae}=$ aerenchyma, $\mathrm{Vb}=$ vascular bundle. The scale bar is $100 \mu \mathrm{m}$. 

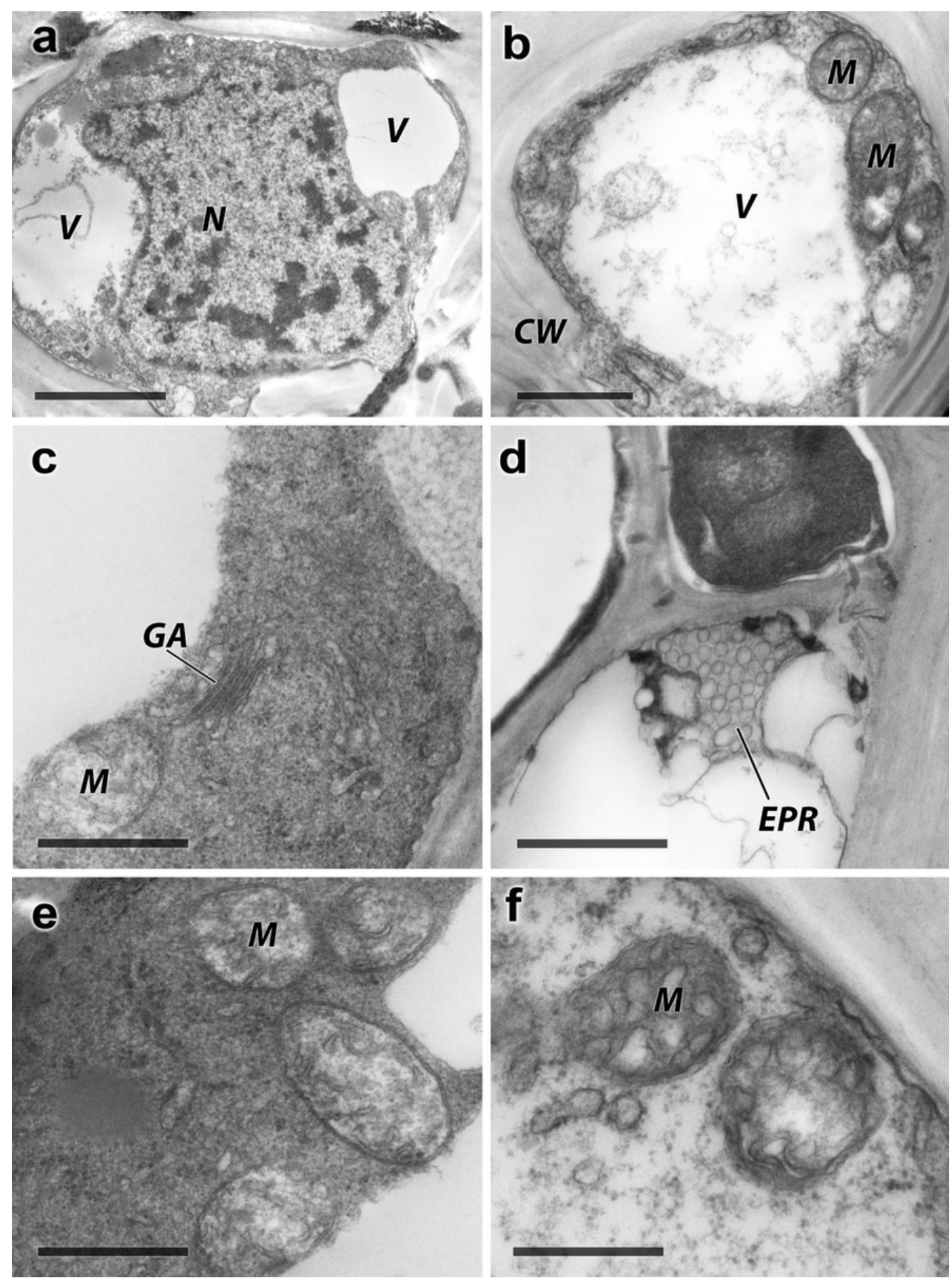

\section{Figure 3}

TEM micrographs of ultrathin cross-sections of the roots in control plants $(a, c, e)$ and polluted plants $(b, d, f) . M=$ mitochondria, $\mathrm{CW}=$ cell wall, $\mathrm{GA}=$ Golgi apparatus, $\mathrm{V}=$ vacuole, $\mathrm{EPR}=$ endoplasmic reticulum. The scale bar $(\mu \mathrm{m})$ is:

a) 2 , b) 1, c) 0.5, d) 1, e) 0.5, f) 0.5 . 

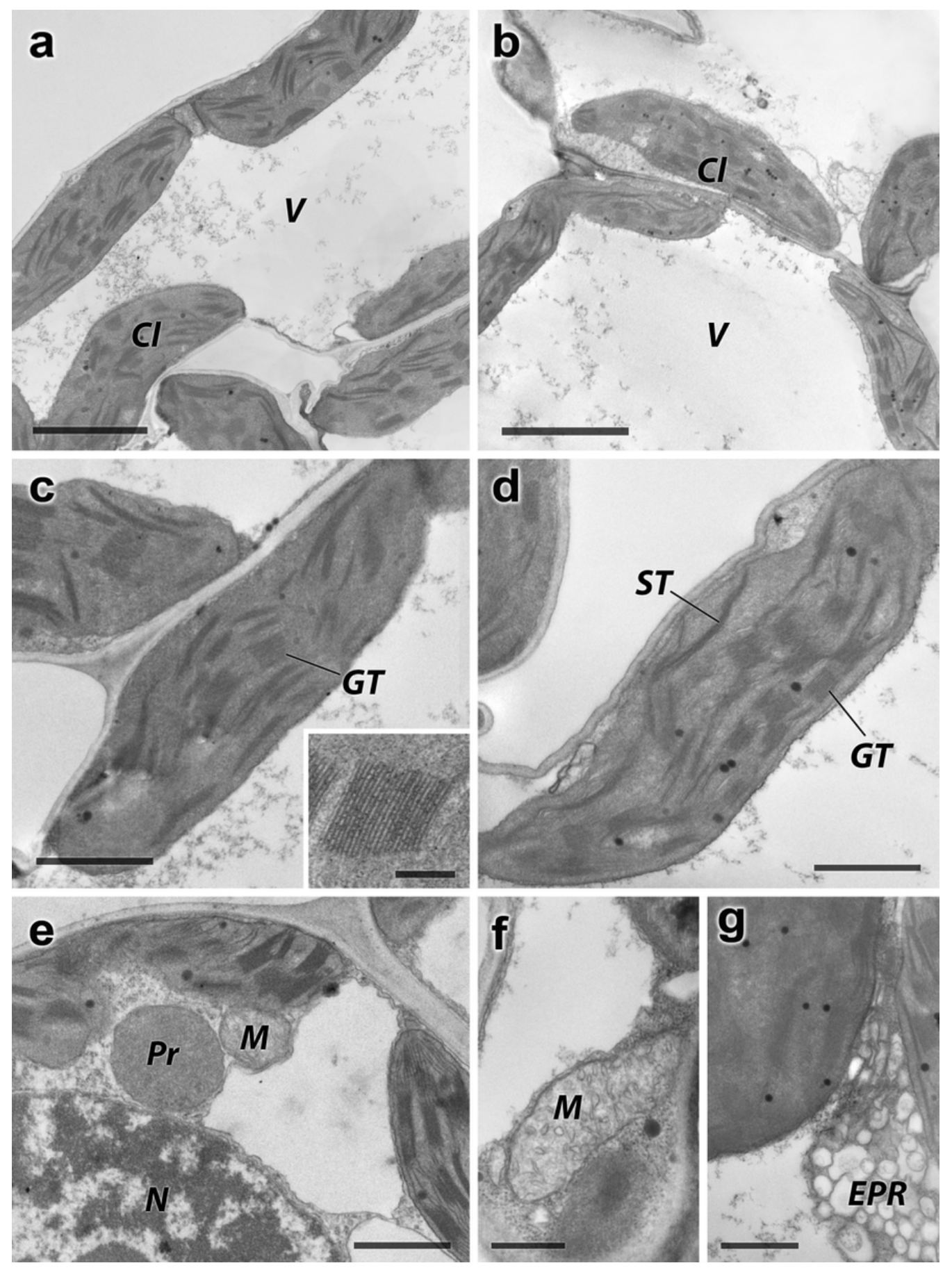

\section{Figure 4}

TEM micrographs of ultrathin cross-sections of leaves from control plants $(a, c, e)$ and polluted plants $(b, d, f)$. CW = cell wall, $\mathrm{Cl}=$ chloroplast, $\mathrm{P}=$ plastoglobuli, $\mathrm{GT}=$ thylakoids gran, $\mathrm{ST}=$ thylakoids stroma, $\mathrm{N}=$ nucleus, $\mathrm{M}=$ mitochondria, $\mathrm{Pr}=$ peroxisomes, $\mathrm{V}=$ vacuole, $\mathrm{EPR}=$ endoplasmic reticulum. The scale bar $(\mu \mathrm{m})$ is: a) $2, \mathrm{~b}) 2$, c) 1 and for insert: 0.2 , d) 1, e) 1, f) 0.5, g) 0.5 . 